\title{
What Does it Mean to Own a Process: Defining Process Owner's Competencies
}

M. Hrabal
Teaching Assistant
Tomas Bata University in Zlín
Faculty of Management and Economics
Czech Republic
D. Tuček
Associate Professor
Faculty of Management and Economics
Czech Republic
Czech Republic
As organizations adopt process orientation, a new managerial role of process owner appears. Process ownership is one of the main pillars and distinguishing features of process oriented organization. To successfully implement business process management and substitute traditional functional hierarchies, process owners should possess certain competencies for process management. Therefore, the aim of this paper is to introduce a competency model of a process owner. A Delphi study was used to identify individual activities and subsequent competencies of a process owner. Three rounds of questioning an expert panel provided consensus for development of competency model. The paper presents results of the Delphi study synthesized into structured competency model of a process owner. The model structures competencies to knowledge, skills and social competencies derived from process owner's responsibilities. Two variations of process owner's competencies which take into account different scope of responsibility were defined.

Keywords: business process management, process owner, process management model, competency model, delphi study.

\section{INTRODUCTION}

Business Process Management (BPM) is a management theory and discipline, which emphasizes organizational processes as means of adding value to a customer. An organizational process can be defined as a set of interconnected activities, which transforms inputs into products required by a customer $[1,2]$. The main characteristic of a process, especially core organizational process, is its cross-functionality. The flow of work can cut across several functional departments in the organization structure [3].

Problems of traditional functional management are functional silos, which are represented by contradictory departmental goals, fragmentation of work, or incompatible applications and databases resulting in duplicities and wasting. Early proponents of the process management, Michael Hammer and James Champy [4] criticized the practice, when the efficiency of single organizational units was achieved at the expense of the efficiency of the whole system. End-to-end processes themselves should be optimized systematically as the whole system. This makes BPM a holistic or systemic management theory. [5, 6]

History of BPM can be traced back to scientific management of Frederick W. Taylor, Total Quality Management approach, Six Sigma or Business Process Reengineering (BPR), therefore modern BPM can be viewed as an amalgam of these disciplines and methods

Received: January 2016, Accepted: August 2017 Correspondence to: Dr. Martin Hrabal, Tomas Bata University in Zlín, Faculty of Management and Economics, Mostní 513976001 Zlín, Czech Republic E-mail: hrabal@utb.cz doi:10.5937/fmet1801138H

(C) Faculty of Mechanical Engineering, Belgrade. All rights reserved
[7]. Not only operative processes such as manufacturing or service delivery, but also so called metaprocesses such as, e.g., Six Sigma and its phases of process improvement - define, measure, analyse, improve and control can be managed as a process [5].

The current state of BPM research is, according to Roeser and Kern [8], focused rather on technical and methodological dimensions of BPM such process modelling and design, impact of BPM on dependent variables, BPM implementation, current status quo, requirements of practitioners on the research focus or operationalization of the BPM. As a result, qualitative research in the field of people and culture can be recommended.

The main aim of this paper is thus to develop a competency model for a process owner so the BPM initiatives can accomplish planned objectives. This paper therefore seeks the answer to this research question:

RQ: Which competencies does process owner need for adequate performance of his or her role?

Identified competencies may be then structured and defined in a model which would provide guidelines and framework for process owner, human resources specialists and BPM project managers.

\section{THE ROLE OF A PROCESS OWNER}

With the idea of cross-functional processes the role of process owner was also developed. One of the main differences between process oriented organizations and functional management is the pillar of process ownership. In the era of BPR process owners were responsible for reengineering and measurement of core processes across an organization. Hammer and Champy [4] recommended that process owner should be open to changes that the reengineering team builds, motivates 
and develops, ensures resources and cooperates with functional managers within a process. For these reasons, process owner should be a member of top management with senior position. Likewise, Davenport and Short [9] stated that processes should be owned, in some case, by senior managers with skills in facilitation and influence.

However, created process structure should not entirely replace the existing organizational structure but to complement it. As Rumler and Brache [10] explain, white spaces between departments in the organization structure are filled with process interfaces and process owners are responsible for the solution of such matters. With the overlap of the process model with the organization, matrix-like organization structure may develop as a consequence. According to Nesheim [11], process owners work in dialogue with functional managers and define key performance indicators, standardize processes, develop competencies and allocate resources in a process.

Also Kohlbacher and Gruenwald [12] attributed to process owners the responsibility for process performance measurement and improvement. In their research in Austrian manufacturing companies, they found that organizations with implemented process ownership together with process measurement exhibit higher performance than companies with only one of these components. Also, another research [13] proved positive effect of process approach, especially process performance measures, process oriented organizational structure and culture, and continuous improvement methods on the overall performance of the organization.

According to the Accenture [14], the role of process owner is important for BPM projects as almost $75 \%$ of respondents, among which are many 500 Fortune companies, declare that business process owners play the leading, supporting or consulting role in these projects. But, there is difference between what process owners should do and what they really do, especially in the initial phases of BPM [15].

There can be found different terms for a process owner in the literature. Harmon [16] uses the term process manager, Panagacos [17] writes about process steward. In this paper, process owner refers to the managerial role and the process manager or steward can be synonyms to this.

\section{Competency modelling}

A competency can be defined as an underlying characteristic of a person that is related to effective or superior performance in a job. Moreover, achieving fit between individual competencies, job demands and organizational environment results in this performance $[18,19]$. These characteristics indicate behaviour and thinking in a long term, among competencies belong motives, traits, self-concept, knowledge and skills [20].

Another possible classification divides competencies into behavioural and technical. The former refers to the behaviour delivering results such as teamwork, communication or leadership. The latter is composed of knowledge and skills. The most frequent applications include recruitment and selection, training and development, performance management, or rewarding. [21]

At the organizational level, [22] identified core competencies as the collective learning, i.e., how to integrate skills and technologies but also organizing the work and the value delivery. Utilizing these core competencies, which are unique for the organization, then results in development of core products and finally to different products in multiple businesses. If management is responsible for this organizational capability, we can deduce that managers themselves need competencies to ensure this matter. And also process owners who orchestrate the work across individual organizational units to deliver value should possess certain competencies.

There were several attempts to define a managerial competency model. Spencer and Spencer [20] listed among managerial competencies development of others, directiveness, teamwork and cooperation, and team leadership. Manager's generic competency model could therefore be composed of impact and influence, achievement orientation, teamwork and cooperation, initiative, developing others, self-confidence, interpersonal understanding, directiveness or assertiveness, information seeking, team leadership, and conceptual thinking.

A project manager's competency model can be found in Loufrani-Fedida and Missonier [23] who identified individual level of functional competencies in projects as customer competencies, technological competencies and project management competencies. These competencies are held by several roles, while project management competency is attributed to project managers. At the organizational level are integrative competencies composed of simultaneous development, project management process and platform for intertrades cooperation. Together, individual functional and organizational integrative competencies form collective project competency. Similarly, Takey and de Carvalho [24] mapped project management competencies and identified project management process, technical, personal, and context and business competencies.

An example of Delphi study utilization to determine entrepreneurial competencies can be found in the work by Robles and Zárraga-Rodríguez [25]. The expert panel agreed on competencies of risk assumption, initiative, responsibility, dynamism, troubleshooting, search and analysis of information, results orientation, change management and quality of work. Another research on entrepreneurial competencies was conducted by Ismail, Zain and Zulihar [26] who tested need of achievement, need of autonomy, need of power, social orientation, self-efficacy, endurance, risk-taking propensity, market awareness, creativity, flexibility, development of social networks or generation of support networks competencies among college students.

BPM related research of competencies can be found in Eicker, Kochbeck and Schuler [27] who developed rather simple competency framework for BPM roles. Another study provided Sonteya and Seymour [28] who derived competencies of business process analyst role and developed competency framework which consists of:

-Fundamental competencies such as analytic thinking, process thinking, and client experience thinking, and mathematical and statistical competencies.

-Business interpersonal competencies composed of facilitation and leadership, business elicitation requirement, communication and trustworthiness. 
-Organizational knowledge.

-Business process orchestration competency structured to BPM driver and promoter, process and value chain modelling, process risk and compliance assessment, and business process improvement.

- Technical competency in Service oriented architecture, enterprise resource planning or user design interface skills.

Besides these competencies, some authors stress the importance of emotional intelligence. Goleman [29] identified five components of the emotional intelligence: self-awareness, self-regulation, motivation, empathy and social skills. Boyatzis and McKee [30] similarly stated that personal competency is determined by self-awareness, self-management, social awareness and relationship management.

\section{METHODOLOGY}

As was indicated in the literature survey, process owners are one of the distinguishing features of a process oriented organization. Thus, competencies needed for a successful performance in this role should be different from the case of traditional functional manager. Often, we can meet with practice, when organization implementing BPM just renames functional managers to process owners or assign process ownership to existing managers within the organization structure. As a result, organization's processes remain fragmented in functional silos.

To define relevant competencies for a process owner, a Delphi study was chosen as a method for obtaining data from experts in the particular field. Delphi study is a method enabling to obtain consensus among experts to a chosen topic. It was developed by the RAND Corporation [31] and, as the name indicates, it is inspired by ancient Greek's oracle. Nevertheless, instead of asking gods, Delphi study gathers an expert panel whose members answer questions to a given topic in several rounds until the consensus is reached [32, 33].

Rules of the Delphi study were set according to Pickard [32]. These rules are:

-Data are collected in writing.

-There is systemic attempt to reach a consensus.

-Expert panel members are given anonymity.

- Two questioning rounds are used at minimum.

-Consensus is most common but occasionally divergence is the result.

The research was therefore conducted in these steps:

-Defining goals and methodology of the research identification of process owner's competencies.

-Addressing professionals in the field of BPM and management by competencies - several specialists from business practice and academics were addressed to participate.

-Establishing expert panel composed of these professionals - eight of addressed specialists agreed on participation.

-Using questionnaires for a three-rounded data acquiring - development of a questionnaire for the first and second round of questioning including pilot testing.

- Assessment of every round and reporting the results to the expert panel- after every round results were evaluated and reported to members of the panel so they could eventually adjust their answers for the next round.

- Completing and reviewing the competency model after the second round the competency model was designed and provided to the panel for the review as a third round of the Delphi study.

Individual experts were chosen according to their professional career and focus connected to BPM such as management consultants, managers and academicians. The expert panel was composed of eight members who declared agreement and willingness to participate in the study. Questionnaires were prepared in online application and distributed via e-mail. Members of the expert panel filled out questionnaires anonymously and after every round an assessment report synthesizing results was provided to them.

The first round of questioning held in July 2015 was focused on the overall goals and appropriate implementation methodology of BPM, selection of process owners, tasks performed by process owners and competencies needed for the execution of these activities. Questions in the first round were formulated as open to obtain a vast and deep insight. Results of the first round were then sent to the expert panel for assessment.

Based on the results of the first round, the second questionnaire, which was held in August 2015 formulated more specific and closed questions. Members of the Delphi study were choosing from predefined options to specify individual tasks and competencies of a process owner. Individual competencies were clustered into groups such as knowledge, skills and social competencies.

After the second round, a competency model was drafted in September 2015 and assessed by the expert panel in the third round of the Delphi study, which took place in October 2015.

\section{RESULTS}

This part reports the main results of the study which is structured according to conducted questioning rounds via the Delphi study. Thereafter, it followed synthesis into the process model and competency model was verified in the third round of the Delphi study.

\subsection{The first round of the Delphi study}

In the first round of the Delphi study the expert panel members presented their view on topics such as the purpose of BPM in an organization, implementation methodology, selection and position of process owners in the organization, their role and basic competencies. Synthesis of the first round's results is presented in the table 1.

Among the goals of BPM were also mentioned public relations or information system implementations. But if the measurement is missing, projects of information systems or communication technologies implementation should not be considered as BPM initiative.

Opinions on the appointment of process owner, respectively his position in the organization structure were various. 
Table 1: Results of the first round of the Delphi study

\begin{tabular}{|c|c|}
\hline BPM purpose & $\begin{array}{l}\text { Improving performance and efficiency of the organization and its processes; cost reduction; } \\
\text { implementation of better management system. }\end{array}$ \\
\hline Implementation methodology & $\begin{array}{l}\text { Top - down approach from top management and strategy to lower layers; continuous and long- } \\
\text { term implementation program composed of several projects; gradual optimization; definition of } \\
\text { BPM goals; setting up a team; schedule and budget; process mapping and modelling; identification } \\
\text { of bottlenecks and elimination of main inefficiencies; process improvement and controlling } \\
\text { (feedbacks setup and reporting). }\end{array}$ \\
\hline $\begin{array}{l}\text { Responsibility for the } \\
\text { implementation }\end{array}$ & $\begin{array}{l}\text { The main responsibility should have CEO or top management generally as a sponsor; in some } \\
\text { circumstances, e.g. in case of bigger and complex organization, a BPM manager should be } \\
\text { appointed, who would report to CEO. }\end{array}$ \\
\hline $\begin{array}{l}\text { Appointment of process } \\
\text { owner }\end{array}$ & $\begin{array}{l}\text { Selection and appointment of process owner should be in the initial phases of the project during } \\
\text { process identification and mapping. E.g. after training and a workshop with top management; } \\
\text { appointment should perform CEO or BPM manager. }\end{array}$ \\
\hline Reporting and subordination & $\begin{array}{l}\text { Process owner should report to CEO or, in case he is appointed, BPM manager; in case of complex } \\
\text { organization, he can report to superior process owner of sponsor of the process group, but always } \\
\text { to member of top management; process owners of core processes should be members of top or } \\
\text { middle management or at least have a voice in the board; process owners in the lower management } \\
\text { are not advised for the lack of power and knowledge of strategy. }\end{array}$ \\
\hline $\begin{array}{l}\text { Tasks od process owner - } \\
\text { planning }\end{array}$ & $\begin{array}{l}\text { Defining process goals, performance indicators, outputs, design and outputs; in case of executive } \\
\text { manager - allocating resources. }\end{array}$ \\
\hline $\begin{array}{l}\text { Tasks od process owner - } \\
\text { organizing }\end{array}$ & $\begin{array}{l}\text { Determining responsibility matrix; process mapping and coordination; assigning technologies, } \\
\text { tools and resources to the activities; defining organization units, assigning people and capacities; } \\
\text { communicating previously defined attributes. }\end{array}$ \\
\hline $\begin{array}{l}\text { Tasks od process owner - } \\
\text { communicating }\end{array}$ & $\begin{array}{l}\text { Setting up communication channels, promoting BPM and the process; participation on training of } \\
\text { employees; applying controlling approach. }\end{array}$ \\
\hline $\begin{array}{l}\text { Tasks od process owner - } \\
\text { team leadership and } \\
\text { development }\end{array}$ & $\begin{array}{l}\text { Facilitating and sharing information, problem solving; interpreting goals, delegating, motivating } \\
\text { and providing feedback; coordinating process team, functional managers and other process } \\
\text { agents/actors. }\end{array}$ \\
\hline Knowledge & $\begin{array}{l}\text { Management and economics; professional knowledge of the field related to the process; } \\
\text { information and communication technology. }\end{array}$ \\
\hline Behaviour & Leadership; rationality - analytical and systemic thinking. \\
\hline Attitudes & $\begin{array}{l}\text { Loyalty, proactivity and openness, clarity and leadership; art of dealing with people, to express a } \\
\text { need; perceiving subordinates as partners, combining directive and underactive approach; resistant } \\
\text { to stress and despair. }\end{array}$ \\
\hline
\end{tabular}

Some respondents stated that it should be full time occupation positioned in the organization structure and defined in the organization rule. Others stated that it is a role not a position. One of the respondents argued that the process owner should be responsible only for the process and not for the resources management. According to him, the process owner acts when the process is malfunctioning and in case of problems in resources,

including workers, he or she contacts particular functional manager. Therefore, particular inclusion of the process owner depends on the very organization and its culture.

The position of the process owner in top or middle management is recommended. Lower layers do not suppose the knowledge of strategy or do not have enough power to implement change. The idea is that top managers in the role of the process owners define process goals, key performance indicators, design and middle or lower functional managers are responsible for the execution of the process tasks. According to one respondent, the positioning process owner in an organization structure does not make sense because processes create unique management structure.
Questions on tasks of a process owner were categorized according to the idea of management as a process: planning, organizing, communicating, controlling and team leadership or development. One respondent criticized this view of phased management and stated that process owner's tasks are mainly process monitoring, making corrections, communicating and negotiating with people responsible for resources in the process. Nonetheless, respondents provided their opinion in the indicated sequence.

Competencies themselves were structured as knowledge including skills, behaviour and attitudes needed for successful performance of the role. Respondents stated their views on this issue, which would provide the basis for a future competency model. Within the first cluster was suggested management and economics knowledge, which was in some cases specified to knowledge of BPM, project management and change management. Followed professional knowledge related to the process group such as, e.g., technologies in production. But this knowledge should not outweigh management skills. Another knowledge was information and communication technologies but without menti- 
oning any Business Process Management System or Suite (BPMS).

In behaviour competency cluster were discussed properties such as leadership, analytical thinking, conceptual approach, social competency and others. One respondent rejected leadership as a process owner is rather technician focused on performance, who is patient, precise, convenient and rational. Another respondent mentioned even environmental orientation.

Among additional competencies were included e.g. thinking in connections, handling disputes resolution, continuous learning and anticipating phenomena, decision making, opportunity to reward employees, informal authority or being executive manager.

\subsection{The second round of the Delphi study}

The second round of the Delphi study was focused on specific tasks and competencies of a process owner's role. They were structured to tasks, managerial and economics competencies, knowledge of information and communication technologies, communication skills and social competencies. Questions were closed and respondents could choose several options to state their opinion.

Summary of the process owner's activities is shown in the figure 1.

Among the most mentioned activities are reporting to superior who should be a member of top management, sponsoring process improvement projects, process performance monitoring and controlling, coor- dinating functional managers, setting responsibility matrix and communicating BPM and process goal in the organization. The process owner should also be a member of BPM management team.

As less important tasks were marked rewarding process team and operators, auditing, designing process, training of the employees in BPM should not be his task at all except for BPM propagation. Other are setting goals and performance indicators, gathering a voice of customer, implementing BPM in the organization as a team member as well as in his own process.

The $40 \%$ of respondents have also chosen process team leadership, budgeting, resources allocation and management, and inputs and outputs parameters definition. Modelling, simulating and repository management were mentioned only marginally, and therefore should not be process owner's primary tasks but of different role such as process architect or analyst.

Some respondents also commented resources management as process owner coordinates human resources but may not influence other resources such as finance. Therefore, he should contact particular functional manager who is responsible for the resources.

The remaining part of the questionnaire was focused on competencies. In the first place, we were interested in managerial competencies because they were stated as most important together with professional knowledge of the field such as technology in case of production processes. Management knowledge is shown in the figure 2.

\section{Process owner's activities}

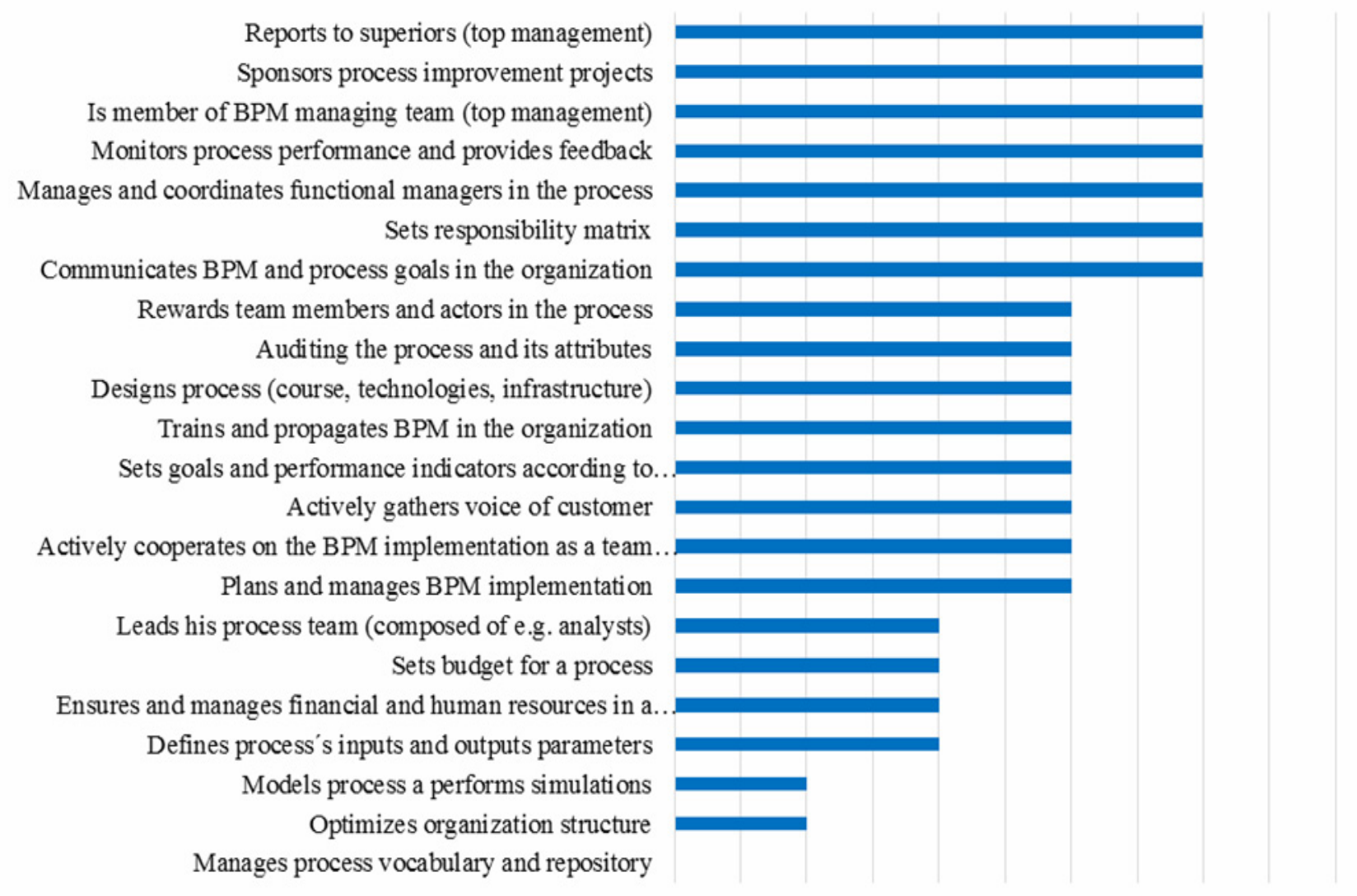




\section{Management knowledge}

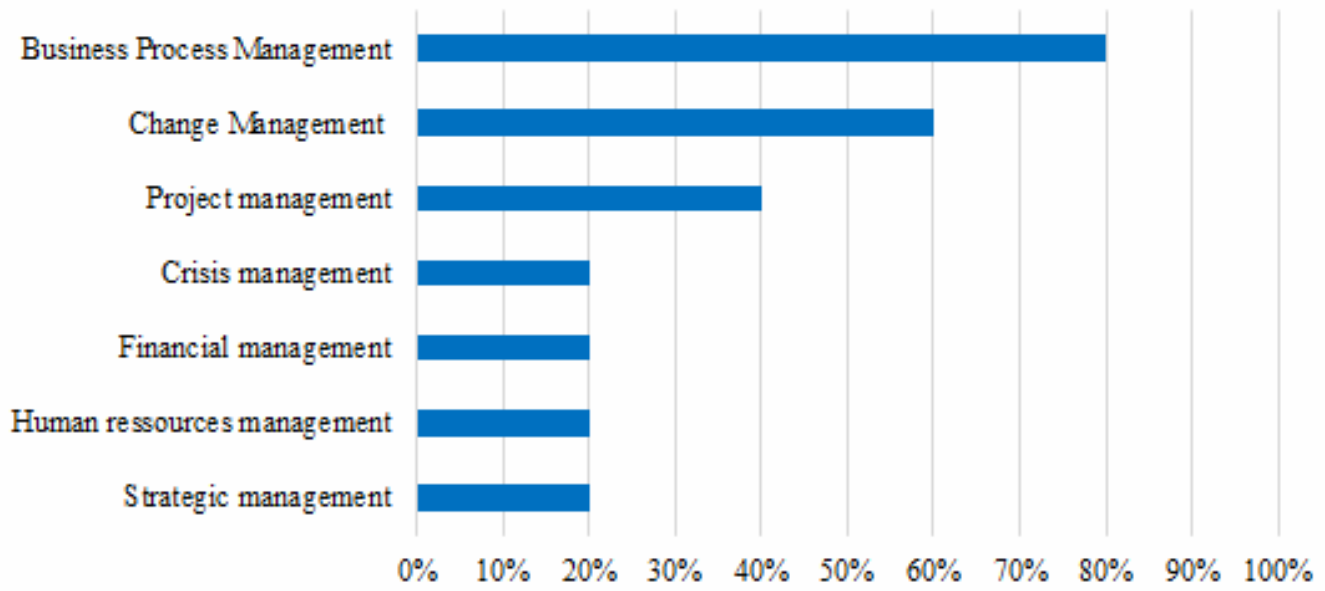

\section{Figure 2: Process owner's management knowledge}

BPM knowledge was designated as the most important part of management knowledge. Then, there followed change management and project management. Other management disciplines are not considered so important. Instead of expertise in these fields, the process owner could have only basic overview. Again, professional knowledge according to the process nature was stressed. The process owner has expertise in the field.

Economic knowledge was not considered as important as management. Figure 3 shows that controlling the process efficiency, calculation and budgeting, and macroeconomic environment was chosen in $40 \%$ of the cases. According to some authors, traditional costing method may not be appropriate to modern business or process management. Therefore, activity based costing and budgeting with throughput accounting were suggested in the questionnaire among economic knowledge of a process owner, but only $20 \%$ of respondents stated the knowledge as relevant. Financial accounting and knowledge of market with customers segments were not chosen at all. Especially the latter is surprising because the process owner should represent to some extent the voice of the customer. To sum up, as one respondent commented, the process owner should collaborate with managers throughout the organization except he is not the owner of financial processes.
As indicated above, expertise in the field of functional area (e.g. production, services, finance) was highly emphasized. These are always dependent on the process itself but generally, there can be included knowledge of external and internal legislation relevant to the process, basic economic and contractual overview. BPM knowledge was repeatedly stated including knowledge of BPM software functionalities. Leadership and employees motivation were mentioned by one respondent as well.

Modern world of business is characterised by expansion of information and communication technologies (ICT), software applications, cloud services or integration platforms. Processes are automated, industries robotized, applications and databases aim to integration. For these reasons, we were interested in ICT knowledge of a process owner. As figure 4 illustrates, BPMS together with traditional office software is the most important. It must be noted that, according to respondents, the process owner should know BPMS at the level of routine user, not as a modeller or repository administrator. Enterprise Resource Planning or Business Intelligence applications can be known at the basic level if necessary.

\section{Economic knowledge}

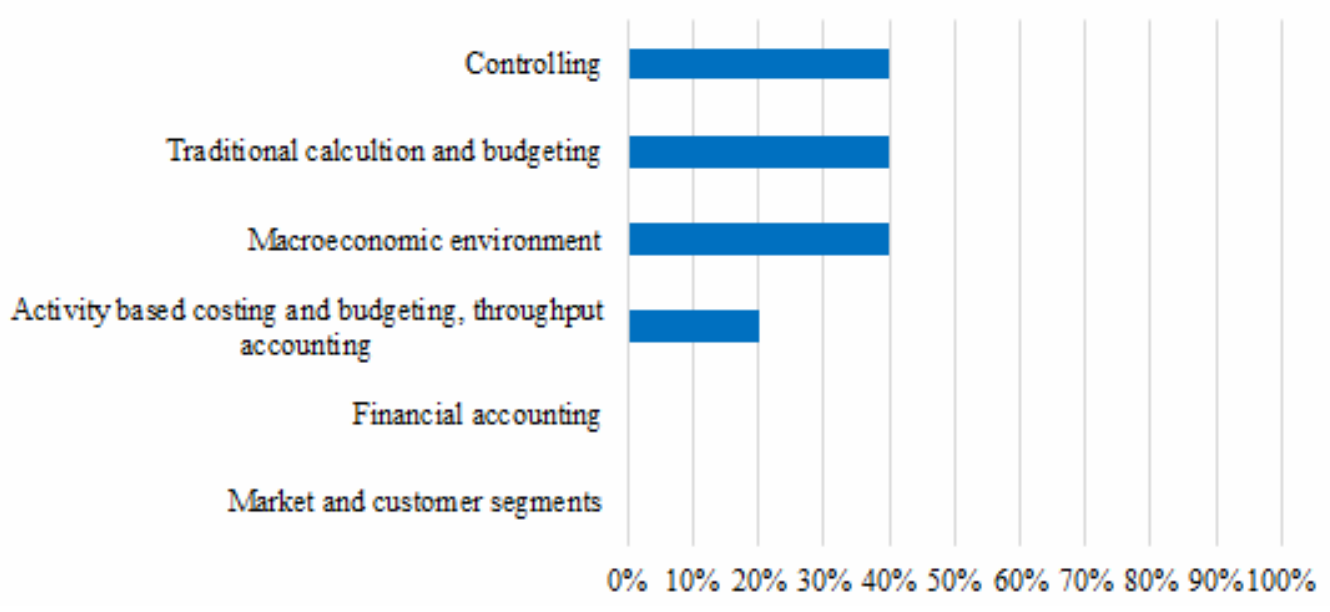

Figure 3: Process owner's economic knowledge 
ICT knowledge

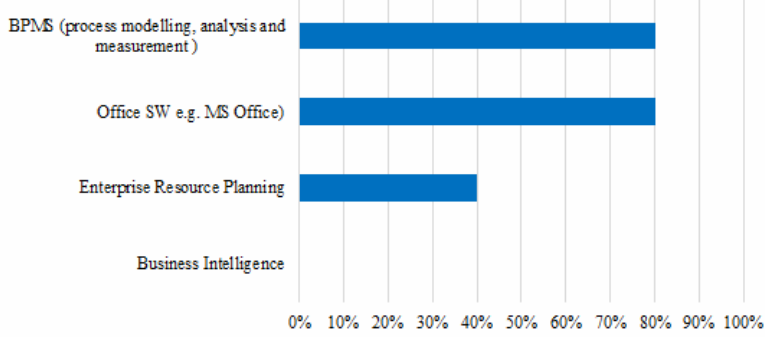

Figure 4: Process owner's information and communication technology knowledge

Communication skills

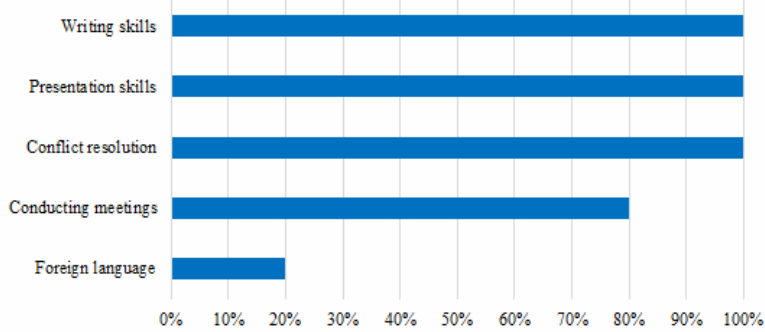

Figure 5: Process owner's communication skills

Following communication skills competency cluster can be viewed as a key to the process owner's competency model. All respondents agreed on the importance of writing and presentation skills and conflict resolution. A meeting management followed by $80 \%$ frequency. Foreign languages were not considered as important; only $20 \%$ of respondents have chosen this option. Results are plotted in table 5 .

To complete the list of knowledge and practical skills, we were interested in other competencies which process owners would need. The process approach is often connected with other disciplines such as TQM, Six Sigma, Lean etc. [7, 16]. Thus, we were interested if process owners should also possess such knowledge. As figure 6 illustrates, respondents agreed that process owner does not necessarily need these skills, but $80 \%$ of them stressed creativity, analytical and systemic thinking. But, these three competencies need not be viewed as skills but as behavioural properties. They should not be mandatory because, e.g., in case of creativity it may be sometimes necessary and sometimes harmful. Best practices and managerial skills together with the process nature should always be in the first place and indicate other competencies.

The last part of questionnaire was focused on social competency cluster. According to expert panel, process owners should be open to new ideas and different opinions, oriented to a customer, be rational and focused on verifiable facts. With $60 \%$ frequency there followed continuous self-education and development, team orientation and loyalty to the organization. Coaching, mentoring and self-awareness and self-management together with leadership followed in $40 \%$ of cases. Focus on interpersonal relationships plays only a marginal role, environmental focus and democratic management style were not chosen at all.

In the end, expert panel agreed on the relevance of the "owned" process itself, which always indicates needed competencies of a process owner. Managerial compe- tency and professional expertise, together with communication skills and BPM training are the most important factors. Other competencies may vary and the competency model should therefore be adjustable or customized for the need of particular organization and its core process.

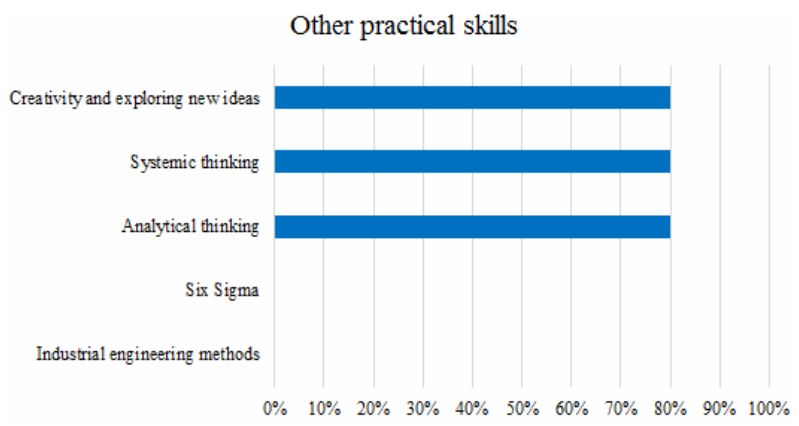

Figure 6: Process owner's other practical skills

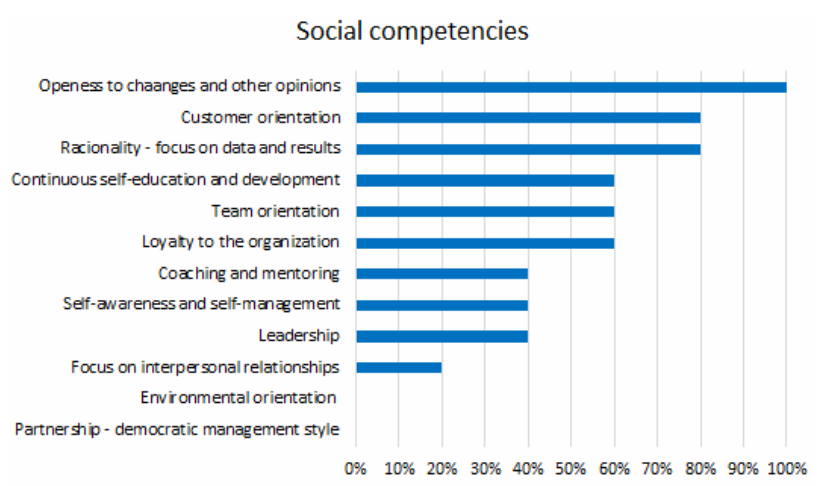

Figure 7: Process owner's social competencies

One respondent added his insight into the topic with a comment that the best approach is "enlightened autocracy". Important is continuous education and training, self-assessment and evaluation consistently, with organization's principles. Other respondent, throughout the Delphi study, emphasized a different view on a process owner. In this view, the process owner does not design the process and manage human resources but merely monitors and evaluates process performance, communicates the results and deals with problems connected with the process. He may have support of a process team and should report to the top management but other activities and derived competencies are redundant, because functional managers are responsible for these activities.

\subsection{Process management model}

Individual competencies should be derived from the tasks and activities, which the specific role has to fulfil. In case of a process owner, we are considering his or her role in a process. Process owner owns or is accountable for the process performance and efficiency, and therefore his or her activities form process management. Based on the results of the second questionnaire, the tasks of the process owner were sequenced and structured in a process model illustrated in figure 8 .

The proposed process model of process management consists of two branches. The first one describes strategic part on BPM, which comprises BPM strategy development, governance definition and core processes identification with the process owners' assignment. The second branch defines process management itself. 


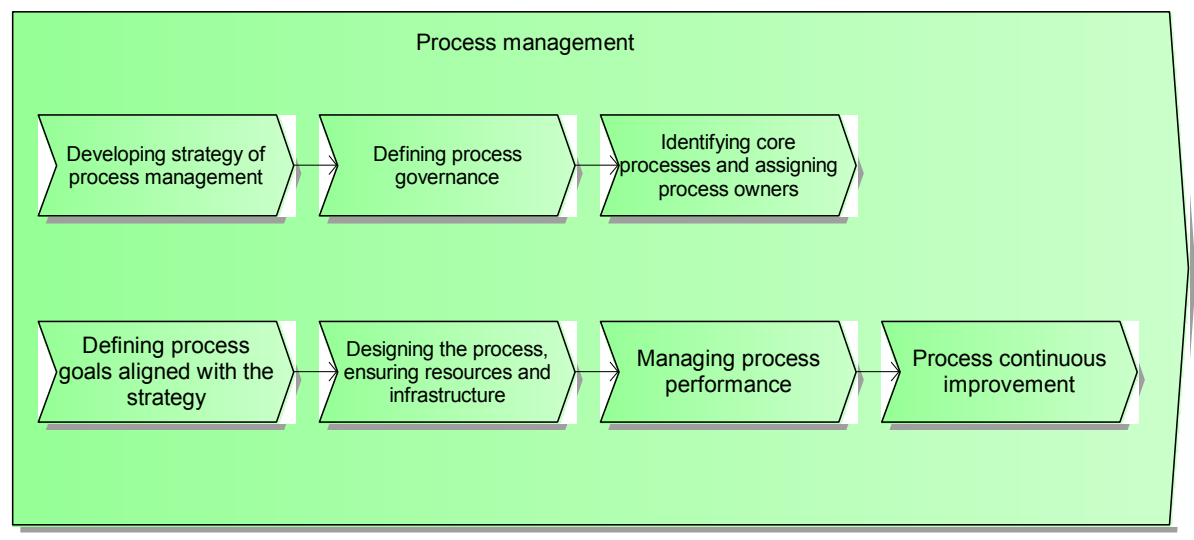

Figure 8: Process management model

It was stated that process owners are assigned in initial phases of a project when processes are identified and mapped. Process owner is a member of the top management team. Therefore, he has a role in developing the strategy of BPM and is responsible for process analysis and modelling performed by a process team. Definition of process governance is dependent on the organization maturity and complexity. Organization may have one process owner with analysts performing analysis and modelling or a manager for BPM with several process owners and process team forming, e.g., the BPM centre of excellence. Although process owners should be assigned after the initial BPM strategy and goals setting, if they are already members of top management, they contributed to the strategy definition and should continuously develop BPM strategy.

The second branch of process management model has four subprocesses: defining process goals aligned with the strategy, designing the process, ensuring resources and infrastructure, managing process performance and process continuous improvement. In the first subprocess, the process owner sets process goals and performance indicators according to the strategy and collected voice of the customer, communicates these goals and propa-gates BPM in the organization. In the second subprocess, he designs the process, develops responsibility matrix and defines inputs and outputs parameters. In case that he or she is also the executive manager, he/she sets a budget and allocates financial and human resources. In the third subprocess, there is coordination of functional managers, process performance monitoring and auditing, providing the feedback including rewarding and reporting tothe top management. Finally, in the fourth subprocess, the process owner sponsors improvement projects. These activities are a prerequisite for the competency model presented below.

\section{PROCESS OWNER'S COMPETENCY MODEL}

The process owner's competency model was developed as a synthesis of the Delphi study results and is structured in two main parts. The first part represents activities or tasks of the process owner as prerequisites for required competencies. The second part is composed of several competency clusters, where individual competencies are included.

Table 2: List of process owner's activities and responsibilities

\begin{tabular}{|l|l|}
\hline Process owner's activities & Activity description \\
\hline $\begin{array}{l}\text { Cooperating on process } \\
\text { strategy and governance }\end{array}$ & $\begin{array}{l}\text { Together with top management defines BPM goals and strategy which then communicate in the organization. } \\
\text { Identifies key processes and subprocesses. Together with his process team implements assigned process. }\end{array}$ \\
\hline $\begin{array}{l}\text { Setting and communicating } \\
\text { process goals }\end{array}$ & $\begin{array}{l}\text { Defines goals and key performance parameters of the process in connection to organizational strategy } \\
\text { and customer requirements. After top management approval and with process team support he } \\
\text { communicates goals to stakeholders. }\end{array}$ \\
\hline Designing the process & $\begin{array}{l}\text { Set inputs, outputs and procedures parameters incl. needed infrastructure. Identifies process interfaces, } \\
\text { develops responsibility matrix and communicates the design within the organization. Process team } \\
\text { cooperates on the design and creates process model which is then approved by the process owner. }\end{array}$ \\
\hline $\begin{array}{l}\text { Managing process } \\
\text { performance and ensuring } \\
\text { feedback }\end{array}$ & $\begin{array}{l}\text { Leads process implementation together with the team and functional managers. Regularly monitors } \\
\text { performance indicators and goals achievement, provides feedback to workers in the process. In case of } \\
\text { problems he initiates resolution. }\end{array}$ \\
\hline $\begin{array}{l}\text { Managing and coordinating } \\
\text { functional managers in the } \\
\text { process }\end{array}$ & $\begin{array}{l}\text { Convenes and leads (regular) meetings with functional managers in the process to solve issues connected } \\
\text { to the process, its attributes and performance. }\end{array}$ \\
\hline Rewarding process team & Is rewarded and rewards the team and workers according to process performance. \\
\hline $\begin{array}{l}\text { Sponsoring process } \\
\text { improvement projects }\end{array}$ & Ensures the support for project managers and teams improving process performance. \\
\hline Reporting to top management & Regularly reports to top management about process performance. \\
\hline $\begin{array}{l}\text { Ensuring and managing } \\
\text { resources in the process } \\
\text { (optional) }\end{array}$ & $\begin{array}{l}\text { In case that process owner is executive manager, he or she sets, ensures and manages resources for the } \\
\text { process incl. financial, material and human resources. }\end{array}$ \\
\hline
\end{tabular}


These clusters are knowledge (managerial, economic, professional, communication and information technology), skills (communication and practical) and social competencies. Developed competency model together with the list of activities were reviewed by the expert panel as the third round of the Delphi study. Comments of the experts served to the test and finalization of the model.

Table 3: List of process owner's knowledge competencies
Every item in the competency model is described in detail to provide information about suitable level of a task or competency. In the table 2 are listed individual activities connected to process management as results from the process model presented above.

The first competency cluster is composed of management, economic, professional and communication and information technology knowledge, as seen in table 3.

\begin{tabular}{|c|c|}
\hline $\begin{array}{l}\text { Cluster of competencies / } \\
\text { competencies }\end{array}$ & Competency description \\
\hline \multicolumn{2}{|l|}{ Management knowledge } \\
\hline Business Process Management & $\begin{array}{l}\text { Knows BPM tenets and differences to functional management. Is able to identify end-to-end } \\
\text { process graphically, assign tasks consequent from process models, monitor performance } \\
\text { indicators and improve the process. Orients in process documentation and job descriptions. }\end{array}$ \\
\hline Change Management & $\begin{array}{l}\text { Realizes the need for innovations and changes. Can define vision of the future, plan, implement } \\
\text { and sustain changes. }\end{array}$ \\
\hline Project Management & $\begin{array}{l}\text { Knows principles of project management. Can define project goals and approves project charter. } \\
\text { Supports project manager and team. Regularly is informed about milestones completion and } \\
\text { takes over process improvement outputs. }\end{array}$ \\
\hline $\begin{array}{l}\text { Basics of other management } \\
\text { disciplines (optional) }\end{array}$ & $\begin{array}{l}\text { Disposes of basics in financial management, human resources management, strategic } \\
\text { management etc. }\end{array}$ \\
\hline \multicolumn{2}{|l|}{ Economic knowledge } \\
\hline Market and economic environment & $\begin{array}{l}\text { Has basic awareness about political and socio-economic environment. Knows the target market } \\
\text { and customers so he or she can define process goals and design. }\end{array}$ \\
\hline Controlling & $\begin{array}{l}\text { Knows principles of financial and process controlling, uses both financial and non-financial } \\
\text { performance indicators. }\end{array}$ \\
\hline Costing and budgeting & Knows principles of cost accounting. With his team he can apply them on the process. \\
\hline Process costing (optional) & Applies activity based costing and throughput accounting to evaluate process costs. \\
\hline \multicolumn{2}{|l|}{ Professional knowledge } \\
\hline $\begin{array}{l}\text { Professional knowledge according } \\
\text { to the process nature }\end{array}$ & $\begin{array}{l}\text { Has professional knowledge consequent to the process, e.g. technologies, software applications, } \\
\text { materials, etc. }\end{array}$ \\
\hline $\begin{array}{l}\text { Knowledge of relevant legislation } \\
\text { and norms }\end{array}$ & $\begin{array}{l}\text { Orients in internal and external legislation relevant to the process such as work law, business } \\
\text { law, ISO norms etc. }\end{array}$ \\
\hline $\begin{array}{l}\text { Knowledge of best practices } \\
\text { (optional) }\end{array}$ & Applies BPM and functional best practices. \\
\hline \multicolumn{2}{|c|}{ Knowledge of information and communication technologies } \\
\hline Office software & Independently uses the office software, i.e. text editor, table processor, e-mail client etc. \\
\hline BPMS & $\begin{array}{l}\text { On user-level uses BPM systems. Knows modelling notations, structure of repository, can view } \\
\text { and analyse process models, monitors performance indicators. Uses software applications } \\
\text { specific to the process (e.g. workflow). }\end{array}$ \\
\hline $\begin{array}{l}\text { Enterprise Resources Planning } \\
\text { (optional) }\end{array}$ & Knows organizational information system and ERP modules relevant for the process. \\
\hline
\end{tabular}


Table 4: List of process owner's skills competencies

\begin{tabular}{|l|l|}
\hline $\begin{array}{l}\text { Cluster of competencies / } \\
\text { competencies }\end{array}$ & Competency description \\
\hline Communication skills & $\begin{array}{l}\text { Listens actively, understands motives and reasons of colleagues' actions. Prevents and solve } \\
\text { conflicts between functional departments in the process, in the interfaces, with customers etc. } \\
\text { Acts politely. }\end{array}$ \\
\hline Conflict resolution & Can express himself or herself intelligibly in the speech, uses visuals to support the presentation. \\
\hline Art of writing & $\begin{array}{l}\text { Can express himself or herself intelligibly and concisely in the written form. Follows the } \\
\text { netiquette. }\end{array}$ \\
\hline Management of meetings & $\begin{array}{l}\text { Leads meetings and debates constructively - sets goal and agenda, provides information in } \\
\text { advance, while problem solving he or she listens to opinions of others. }\end{array}$ \\
\hline Other practical skills & $\begin{array}{l}\text { Divides the problem on lesser parts to assess them independently and in interconnections incl. } \\
\text { separating important and non-important information. }\end{array}$ \\
\hline Analytical thinking & $\begin{array}{l}\text { Distinguishes relationships and associations between parts forming the whole - the system. Can } \\
\text { identify trends and changes. }\end{array}$ \\
\hline Systems thinking & $\begin{array}{l}\text { Favours innovation in case they lead to process improvement. Seeks harmony between } \\
\text { standardization and creativity. }\end{array}$ \\
\hline $\begin{array}{l}\text { Creativity and searching new } \\
\text { possibilities }\end{array}$ & $\begin{array}{l}\text { Knows the principles of lean production and waste elimination, statistical quality control and } \\
\text { DMAIC process improvement. }\end{array}$ \\
\hline Lean a Six Sigma (optional) &
\end{tabular}

Table 5: List of process owner's social competencies

\begin{tabular}{|c|c|}
\hline $\begin{array}{l}\text { Cluster of competencies / } \\
\text { competencies }\end{array}$ & Competency description \\
\hline \multicolumn{2}{|l|}{ Social competencies } \\
\hline $\begin{array}{l}\text { Openness to change and other } \\
\text { opinions }\end{array}$ & $\begin{array}{l}\text { Is open to innovations and different opinions. Can assess them critically and potentially ensure } \\
\text { realization. }\end{array}$ \\
\hline Rationality & Orients on the facts and results, decides the basis of verifiable data and information. \\
\hline Customer orientation & $\begin{array}{l}\text { Represents the voice of customer of the process during the design, performance measurement } \\
\text { and improvement. }\end{array}$ \\
\hline Loyalty to the organization & Interests of the organization are first, personal interests second. \\
\hline Teamwork orientation & $\begin{array}{l}\text { Prioritizes teamwork. Knows team roles and can build a team composed of complementary } \\
\text { individuals. }\end{array}$ \\
\hline $\begin{array}{l}\text { Continuous self-education and self- } \\
\text { development }\end{array}$ & Develops his of hers knowledge in the field, management and general overview. \\
\hline Leadership (optional) & Defines the vision, inspires colleagues to continuous improvement. \\
\hline $\begin{array}{l}\text { Self-control and self-management } \\
\text { (optional) }\end{array}$ & $\begin{array}{l}\text { Understands his or her emotions, strengths and weaknesses and can manage them. Acts with } \\
\text { integrity, is flexible, initiative and optimistic. }\end{array}$ \\
\hline Coaching and mentoring (optional) & $\begin{array}{l}\text { Applies not only directive management approach but also coaching and mentoring. Can be } \\
\text { teacher or lead colleagues so they can solve problems themselves. }\end{array}$ \\
\hline
\end{tabular}

And last, but not the least, there is a social competencies cluster composed of various stances and behaviours. The social competencies cluster is stated in the table 5 .

\section{DISCUSSION}

Presented competency model represents the synthesis of the expert panel members' opinions achieved via the Delphi study. Competencies are derived from tasks and activities, therefore are result and performance oriented. The competency model itself is structured into several competency clusters: knowledge, skills and social competencies. Knowledge competencies include managerial, economic, information and communication technology, and professional knowledge specific for a process nature. Among skill belong communication, analytical and systemic thinking, and creativity in process design and innovation. Social competencies form openness, rationality, customer orientation, loyalty, teamwork and self-improvement.

Two variants of the process owner were identified. The first one views process owner as an executive manager with responsibility for the process and resources, including human resources alike. The second one favours a rather simpler concept of the process owner responsible for assigned process and its performance, whether functional managers keep responsibility for the resources. In this view, process owner monitors the process, its inputs, outputs and execution parameters and indicators. In case of incompatibility within the process, the process owner 
ensures compliance or improvement. But in case of an issue in the resources or employees, process owner informs the responsible manager to deal with the issue. As a result, the developed competency model includes activities and competencies which are optional, especially ensuring and managing resources in the process and consequently leadership competency.

The variance may represent the diversity of structures in business environment. Every organization has its needs and culture and thus its perception of the process ownership may vary. Even the experts in the field have different opinions on some topics, as was found especially in the first round of the Delphi study. In some organizations, process owners may be full time managers, in other they can be part time roles. Moreover, some organizations have additional structures of product managers or other concepts, which increase hierarchies and complexities. It is a potential for further research in business environment to analyse these approaches and identify best practices.

The competency model was developed as a concept for further research. Results of the Delphi study may provide rather ideal concept for the process owner's role, and therefore empirical testing with customization for an organization's needs should be conducted. It is suitable to complement it by scales and requirements thresholds for process owners, which would be tailormade according to particular organization. Then, competency model can be utilized in BPM projects to help with selection and assignment of process owners, development and assessment of process owner's competencies, and therefore, support successful achievement of BPM goals within an organization.

Further research may be focused on the empirical testing of the model used in practice or on the development of body of knowledge about other BPM related roles such as analysts, business and information technology architects, risk and compliance managers etc. Analysis of jobs, roles and their competencies may provide deeper insight into BPM as a managerial discipline and not only technology for process execution. Human factor plays an important role in every business and BPM should be no exception. Management by competencies can provide the basis for BPM initiatives and interconnect process management with human resources management.

\section{CONCLUSION}

Process owner is a managerial role distinguishing the process focused on organization compared to traditional functional organizations. Switch in the organization toward process orientation requires specified competencies. This paper sought the answer to the research question, on which competencies process owners need to successfully manage their processes. Tasks, activities and consequent competencies were identified via the Delphi study. Several questioning rounds with the expert panel provided rich data and insight. Results of two rounds were synthesized to a competency model, which was tested in the third round of the Delphi study.

Proposed competency model is structured into a list of activities and competency clusters with individual competencies. These clusters include knowledge, skills and social competencies. Knowledge comprises managerial, economic, ICT and professional knowledge. Skills are composed of communication skills, analytical and systemic thinking, and creativity and innovativeness. Social competencies emphasize openness to change, customer orientation, rationality or loyalty to the organization.

It is suitable to customize the model according to particular organization's needs. Also, one of the two variants of the competency model is available. The first proposes a process owner as an executive manager with, e.g., leadership competency, the second one views process owner without responsibility for resources. The former manages both the process and the resources; the latter monitors the process, improves its performance and in case of problems in resources, process owner initiate negotiation with functional managers. The variance of approaches may be caused by uniqueness and complexity of companies and business environments.

The competency model can be utilized for the process owners' selection and assignment, competencies assessment and development. Competent people in this role may therefore support successful BPM implementation and subsequent development of the BPM maturity.

Future research will be focused more on empirical qualitative research of companies developing their process approach and maturity. Identification of their additional BPM roles and competencies would complement the model of process owner. Similar competence models for other BPM roles should be tested in practice and then may improve the BPM maturity and contribute to overall efficiency of an organization.

\section{ACKNOWLEDGMENT}

The authors are grateful to the Internal Grant Agency of FaME TBU No. IGA/FaME/2014/008 (Process Owner's Competency Model in the System of Process Managed Education) for financial support to carry out this research.

\section{REFERENCES}

[1] Hammer, M.: The agenda: What every business must do to dominate the decade, Three Rivers Press, New York, 2003.

[2] Lehmann, C.: Strategy and business process management: Techniques for improving execution, adaptability, and consistency, CRC Press, Boca Raton, FL, 2012

[3] Robson, M. , Ullah, P.: A practical guide to business process re-engineering, Gower, Aldershot, England, 1996

[4] Hammer, M., Champy, J., Reengineering the corporation: A manifesto for business revolution, HarperBusiness Essentials, New York, 2003.

[5] Smith, H., Fingar, P.: Business process management: The third wave (4th Anniversary ed), Meghan-Kiffer Press, Tampa, Fla, 2007.

[6] Segatto, M. et al.: Business process management: a systemic approach? Business Process Management Journal, Vol. 19, No. 4, pp. 698-714, 2013.

[7] Jeston, J., Nelis, J.: Business process management: Practical guidelines to successful implementations (Third ed.), Routledge, New York, 2014. 
[8] Roeser, T. Kern, E. M., Surveys in business process management - a literature review, Business Process Management Journal, Vol. 21, No. 3, pp. 692 718, 2015.

[9] Davenport, T. H., Short J. E., The New Industrial Engineering: Information Technology and Business Process Redesign, Sloan Management Review, Vol. 31, No. 4, pp. 11-27, 1990.

[10] Rummler, G., Brache, A.: Improving performance: how to manage the white space on the organization chart (Updated ed., 3rd ed.), Jossey-Bass, San Francisco, 2013.

[11] Nesheim, T., Balancing process ownership and line management in a matrix-like organization. Knowledge and process management, Knowledge and Process Management, Vol. 18, No. 2, pp. 109-119, 2011.

[12] Kohlbacher, M., Gruenwald, S., Process ownership, process performance measurement and firm performance, International Journal of Productivity and Performance Management, Vol. 60, No. 7, pp. 709-720, 2011.

[13] Kohlbacher, M., Reijers, H., The effects of processoriented organizational design on firm performance, Business Process Management Journal, Vol. 19, No. 2, pp. 245-262, 2013.

[14]Accenture - BPM Governance in Practice, Retrieved November 12, 2015, from http://www. researchgate.net/publication/259755325 Research Study_-_BPM_Governance_in_Practice, 2013.

[15]Reijers, H. A. et al.: Process Owners in the Wild: Findings from a Multi-method Descriptive Study, in: Proceedings of the 1st International Workshop on Empirical Research in Process-Oriented Information Systems, Hammamet, Tunisia, 2010.

[16] Harmon, P.: Business process change: A business process management guide for managers and process professionals (Third ed.), Elsevier/Morgan Kaufmann, Amsterdam, 2014.

[17] Panagacos, T.: The Ultimate guide to business process management. USA: [Place of publication not identified], 2012.

[18] Boyatzis, R.: The competent manager: A model for effective performance, Wiley, New York, 1982.

[19] Boyatzis, R., Competencies in the 21st century. Journal of Management Development, Vol. 27, No. 1, pp. 5-12, 2008.

[20] Spencer, L. et al.: Competency at work: Models for superior performance, Wiley, New York, 1993.

[21] Armstrong, M., Taylor, S.: Armstrong's handbook of human resource management practice, 13th edition (13th ed.), Kogan Page, London, 2014.

[22] Pralahad, C., Hamel, G., The Core Competency of the Corporation, Harvard Business Review, Vol. 68, No. 3, pp. 79-91, 1990.

[23] Loufrani-Fedida, S., Missonier, S., The project manager cannot be a hero anymore! Understanding critical competencies in project-based organizations from a multilevel approach, International Journal of
Project Management, Vol. 33, No. 6, pp. 12201235, 2015.

[24] Takey, S., De Carvalho, M., Competency mapping in project management: An action research study in an engineering company, International Journal of Project Management, Vol. 33, No. 4, pp. 784-796, 2015.

[25] Robles, L., Zárraga-Rodríguez, Key Competencies for Entrepreneurship, in: Procedia Economics and Finance, Vol. 23, pp. 828-832, 2014.

[26] Ismail, V., Zain, E., \& Zulihar, The Portrait of Entrepreneurial Competency on Student Entrepreneurs, in: Procedia - Social and Behavioral Sciences, Vol. 169, pp. 178-188, 2015.

[27] Eicker, S. et al., Employee Competencies for Business Process Management, Business Information Systems, Vol. 7, 251-262, 2008.

[28] Sonteya, T., et al., Towards an Understanding of the Business Process Analyst: An Analysis of Competencies. Journal of Information Technology Education: Research, Vol. 11, pp. 43-63, 2012.

[29] Goleman, D., What Makes a Leader? Harvard Business Review, Vol. 76, No. 6, pp. 82-91, 1998.

[30] Boyatzis, R., \& McKee, A.: Resonant Leadership: Renewing yourself and connecting with others through mindfulness, hope, and compassion, Harvard Business School Press, Boston, 2005.

[31]Dalkey, N., \& Helmer, O., An Experimental Application of the Delphi Method to the Use of Experts, Management Science, Vol. 9, No. 3, pp. 458-467, 1963.

[32] Pickard, A.: Research methods in information (2nd ed.), Facet, London, 2013.

[33] Mertens, D.: Research and evaluation in education and psychology: integrating diversity with quantitative, qualitative, and mixed methods. (4th ed.), Sage, Los Angeles, 2015.

\section{NOMENCLATURE}

BPM Business Process Management

BPMS Business Process Management Suit / System

BPR Business Process Reengineering

CEO Chief Executive Officer

DMAIC Define, Measure, Analyse, Improve, Control

ERP Enterprise Resource Planning

ICT Information and Communication Technology

ISO International Organization for

Standardization

RAND RAND Corporation (Research and

TQM Total Quality Management

\section{ШТА ЗНАЧИ БИТИ ВЛАСНИК ПРОЦЕСА: ДЕФИНИСАҢЕ КОМПЕТЕНЦИЈА ВЛАСНИКА ПРОЦЕСА}

\section{М. Храбал, Д. Тучек}

Са усвајањем процесне оријентације у радној организацији се појављује нова менаџерска улога: 
власник процеса. Власништво процеса је једна од основних карактеристика радне организације оријентисане на процес. У циљу успешног управљања процесом пословања и замене традиционалне хијерархије функција, власници процеса треба да поседују одређене компетенције за управљање процесом. Зато је циљ овог рада био увођење модела компетенција власника процеса. Индивидуалне активности и компетенције власника процеса одређене су помоћу Делфи студије. Модел компетенција је развијен на основу консензуса постигнутог после интервјуа експертског панела спроведеног у три круга. У раду су приказани резултати Делфи студије који су послужили за развијање структурираног модела компетенција власника процеса. Структуру модела чине компетенције као што су знања, вештине и социјалне компетенције изведене из одговорности власника процеса. Дефинисане су две варијанте компетенција власника процеса, које узимају у обзир различит обим одговорности. 